\title{
IAMJ
}

INTERNATIONAL

AYURVEDIC

MEDICAL JOURNAL

ISSN: 2320-5091

Impact Factor: 6.719

\section{A CRITICAL REVIEW ARTICLE ON PANDU W.S.R. ANAEMIA}

\author{
Shivam Kumar Nigam ${ }^{1}$, Rita Singh ${ }^{2}$, Sanjay Srivastava ${ }^{3}$ \\ ${ }^{1}$ PG Scholar, Rog Nidan \& Vikriti Vigyan \\ ${ }^{2}$ Reader, Rog Nidan \& Vikriti Vigyan \\ ${ }^{3}$ Professor and HOD, \\ Rog Nidan \&Vikriti Vigyan Pt. Khusilal Sharma Government (Autonomous) Ayurveda Institute, Bhopal, \\ Madhya Pradesh, India
}

Corresponding Author: nigamshivam143@gmail.com

https://doi.org/10.46607/iamj3409092021

(Published Online: September 2021)

Open Access

(C) International Ayurvedic Medical Journal, India 2021

Article Received: 23/08//2021 - Peer Reviewed: 03/09/2021 - Accepted for Publication: 04/09/2021

\section{Check for updates}

\section{ABSTRACT}

Pandu Roga is one of the diseases mentioned in Ayurveda characterized by the changes in the skin colour to white (Shweta), yellowish (Peeta), greenish (Harita) etc. which is one of the "Varnopalakshita Roga" i.e., a disease characterized by the change in the colour. The clinical condition of Pandu in Ayurveda can be co-related with Anaemia described in Modern Medical Science, due to the resemblance in the clinical signs and symptoms. In Modern Medicine, Pandu is a pale appearance which may be due to the decreased blood supply to the skin or decreased visibility of oxyhemoglobin. Anaemia is a major global public health problem and the most prevalent nutritional deficiency disorder in the world. This article presents the Ayurvedic concept of Pandu Roga (Anaemia).

Keywords: Pandu, Vyadhi, Srotas, Anaemia, Pallor,

\section{INTRODUCTION}

Ayurveda is the science of life that is focused on the maintenance of positive health in healthy and eradi- cation of ailments in diseased through its holistic approach, lifestyle practices, dietary habits, and safer 
medications. Malnutrition either due to inadequate dietary intake or lack of balanced diet and population explosion in today's world has led to the development of various diseases and Pandu Roga is one of such diseases. Ayurveda described Pandu as Pitta Pradhana Vyadhi associated with Rasa and Rakta Dhatu. Dhatus nourishment mainly affects disease due to Pitta Prakopaka Ahara. ${ }^{[1]}$ Pandu Roga is one of the Varnopalakshita Roga mentioned in Ayurveda characterized by the changes in the skin colour to white (Shweta), yellowish (Peeta), greenish (Harita) etc. ${ }^{[2]}$ Acharya Charak and Vagbhatta accepted Pandu Roga as a disease of Rasavaha Strotas, while according to Sushruta it is of Rautavaara Srotas ${ }^{[3]}$

Pandu Roga is characterized by the paleness of the body which may be due to reduced blood flow and oxygen or by a decreased number of red blood cells and Anaemia is one of the most common causes of paleness so Pandu Roga can be correlated with Anaemia. ${ }^{[4]}$ Anaemia refers to a state in which the level of haemoglobin in the blood is below the reference range appropriate for age and sex. ${ }^{[5]}$

Anaemia is a major global public health problem having an influence on health as well as social and economic development affecting both developing and developed countries. ${ }^{[6]}$ Anaemia is the most prevalent nutritional deficiency disorder in the world. ${ }^{[7]}$ Globally, Anaemia affects 1.62 billion people, which corresponds to $24.8 \%$ of the population. ${ }^{[8]}$ In India, Anaemia affects an estimated $50 \%$ of the population. [9]

In Ayurveda concept of Pandu is abundantly and mentioned in various literature. The knowledge of this concept is very beneficial to treat different disorders where Pandu is a symptom and disease itself. This article presents the Ayurvedic concept of Pandu Roga (Anaemia). Hence, in this article attempt has been made to review various available Samhita, Samgrahagrantha to find out the different descriptions about Pandu and bring all of them in a single place.

\section{AIM AND OBJECTIVES:}

To review the concept of Pandu Roga from different Ayurvedic literature.

\section{MATERIAL AND METHOD:}

Material has been collected from ancient Ayurvedic texts, Research Journals, and electronic databases.

\section{REVIEW OF LITERATURE:}

\section{VYUTPATTI:}

The word Pandu is derived from 'Padi Nashane' Dhatu by adding 'Ku Pratyaya to it, the meaning of which is always taken in the sense of Nashana and as Pandu has been kept under the group which is classified and named according to the change in colour. ${ }^{[10]}$

\section{NIRUKTI OF PANDU:}

1. According to Shabdarnava Kosh 'Pandustu Peetbhagardh Ketaki Dhulisannibham' means Pandu is like the colour of pollen grains of Ketaki flower which is whitish yellow. ${ }^{[1]}$

2. 'Pandutwenuplakshito Rogah Pandu Rogah' means the disease which resembles Pandu Varna is known as Pandu. ${ }^{[12]}$

\section{DEFINITION OF PANDU: ${ }^{[13]}$}

Sarveshu Chaiteshvih Pandubhavo Yatoadhikoatah Khalu Pandurogah. (Su.Ut. 44/4)

It is called Pandu Roga because of the predominance of paleness all over the body.

\section{SYNONYMS}

According to Shushrut Kamala, Panki, Laghrak, Alas and Kumbhahwa are the synonyms of Pandu. ${ }^{[14]}$

In Rigveda and Atharvaveda Pandu has been described by the name of Vilohita, Halima and Haribha. ${ }^{[15]}$

\section{TYPES OF PANDU ROGA}

Acharya Charak described the disease under five categories namely Vataja, Pittaja, Kaphaja, Sannipataja and Mridabhakshanajanya ${ }^{[16]}$ and Acharya Susrutha has accepted only four types of Pandu excluding Mridabhakshanjanya Pandu ${ }^{[17]}$, they are:

1. Vataj Pandu

2. Pittaj Pandu

3. Kaphaj Pandu

4. Sanipataj Pandu

5. Mridikabhakshanjaya Pandu

Acharya Harita mentioned eight types of Pandu in Harita Samhita and described Kamla, Kumbhakamla, Halimaka as their Synonyms. ${ }^{[18]}$ 


\section{SAMANYA NIDAAN (CAUSATIVE FACTORS):} [19], [20]

The etiological / Samanya Nidana of Pandu Roga mentioned in Charka, Sushruta and other Samhitas can be broadly classified into 3 groups. (Charka Chikitsa 16/8; Sushruta Uttarsthan 44/3)

1. Aharaj Nidana.

2. Viharaj Nidana.

3. Mansik Nidana

4. Other diseases i.e., Nidanarthaka Roga.

1) Aharaj Nidana- Food or diet plays an important role in the normal development and maintenance of different Dhatus as well as in the vitiation of Dosha.

- Excess intake of kshaar (alkaline), amla (sour), lavan (salt), ushna (hot) and teekshna (penetrating) Ahaar.

- The food/Ahara which is virudhha (incompatibles) and asatmya (unwholesome)

- Intake of Nishpav, Masha, Pinyak and Til Tail in excess.

- Excess consumption of wine (Madya), eating mud (Mrida) and Mridu Ahaar

2) Viharaj Nidana:

- Excessive Diwaswapan, Vyayama and Maithun.

- Pratikarma Vaishmaya (faulty administration of panchakarma) and Ritu Vaishamay (faulty management of seasonal regimen)

- Suppression of natural urge (Vega Dharan)

3) Mansik Nidana:

- Mansik nidan i.e., anxiety, fear, anger, and grief have a major role in the manifestation of Pandu.

4) Other /Secondary/Nidanarthaka causes - In Ayurvedic literature there is an indication of a correlation between various diseases and Pandu Roga either as a symptom or as Upadrava. So, all these can be causes of Pandu i.e., Nidanarthaka Roga of Pandu. E.g., Raktatipravartana, Raktaarsha, Raktarbuda, Asrigdara or Raktapradara, Rajyakshama, Punaravartaka Jwara etc. which can directly or indirectly vitiate Vata-Pitta Dosha singly or in combination and manifest as Pandu Roga.

\section{PURVARUPA (PREMONITORY SYMPTOMS):}

According to Acharya Charak: ${ }^{[21]}$

Tasya Lingam Bhavishytah Hridyaspandanam Rokshyam Swedabhavah Shramsatatha. (Ch. Chi. 16/12)

Hridyaspandanam (Palpitation), Rokshyam (dryness of the skin), Swedabhavah (absence of sweating), Shramsatatha (fatigue)

According to Acharya Sushruta: ${ }^{[22]}$

Twaksphotnam

Shthevangatrasadoo

Mridbhakshanam Prekshankootsothah.

Vidmutrapitatwamathaavipako Bhavishtasya Purahsarani. (Su.U. 44/5)

Twaksphotnam (cracking of skin), Shthevan (salivation), Gatrasada (sense of lassitude in the limbs), Mridbhakshanam (liking for mud intake), Prekshankootsothhah (swelling over eye socket), Vid-Mutra Pitata (yellow colour of stool-urine), Avipaka (Indigestion) these are mentioned by Sushruta.

\section{RUPA (SYMPTOMS):}

Acharya Charak has mentioned the Samanya and Vishesh rupa of Pandu Roga in chapter 16 of Chikitsa Sthaan according to the Dosha involvement which is mentioned below.

Samanya Rupa: ${ }^{[23]}$

- Loss of Indriye Bala, Tej, Veerya and Oja.

- Loss of Bala, Varna and Agni (power of digestion).

- Karnashveda (tinnitus), Durbalya (general weakness), Annadwesha (aversion towards food), Shrama (fatigue), Bhramanipidita (giddiness), Gatrashula (body ache), Jwara (fever), Shwasa (breathlessness), Gaurva (heaviness), Aruchi (anorexia).

- Akshikutashoth (swelling over orbit), Shirnaloma (hair fall), Hataprabha (body complexion become greenish)

- Kopana (dislikes cold things), Nidralu (feeling of drowsiness), Alpawaka (avoid speaking), Shtheevan (spitting frequently)

- Pindikodweshthana (calf muscle pain), KatiuruPaad Ruka (pain and weakness in the lumbar, thighs and feet), Arohaneayasa (patient feels exhausted on climbing) 
Vishishta Rupa: Acharya Charka had classified Pandu Roga into 5 types; based on these types Vishesh Rupas are described. [24], [25]

1. Vataj Pandu: - Krishna-Panduta (black and paleyellow discolouration), Rukshata (roughness), Aruna-Angatam (Reddishness of the body), Angmarda (body ache), Ruja (pain), Toda (Pricking type of pain), Kampa (tremor), Parshvashiroruja (pain in chest-head), Varchashosh (dryness of stool), Aashyavairasya (distaste in mouth), Shopha (edema over body parts), Aanah (constipation), Bala-Kshaya (weakness).

2. Pittaja Pandu:- Pita-Haritabhata (complexion become either yellow or green), Jwara, Daha (burning sensation), Trishna (excessive thirst), Murcha (fainting), Pipasa, Pitamutrashakruta (yellowish discolouration of urine and stool), Sweda (profuse sweating), Sheetakamta (increase desire to take cold things), Katukasayta (feeling pungent taste in mouth), Ushnaamlanupashyata (uneasiness for hot and sour things), Vidahe vidagadhe Anne (feeling of burning sensation during indigestion of food), Daurgandhya (foul smell of body), Daurbalya (weakness), Bhinnvarcha (diarrhea)

3. Kaphaja Pandu:-Gaurava (heaviness), Tandra (Drowsiness), Chhardi, Shvetavbhasta (whitish complexion), Praseka (excessive salivation), Lomoharsha (Horripilation), Murchha (Fainting), Bhrama (giddiness), Klama (mental fatigue), Sada (looseness of body parts), Kasa, Shwasa (dyspnoea), Alasya (laziness), Aruchi (anorexia), Vaka-swaragraha (obstruction of speech and voice), Shukla Mutra-Akshivarchasa (whitish discolouration of urine, eye and stool), Katurukshoshna Kamta (feeling to take pungent, Hot and dry things), Shwayathu, Madhurasyata (sweetishness in mouth).

4. Tridoshaja Pandu: - Sign and symptoms of all the three vitiated Doshas are present, and this is extremely intolerable because of developing complications.

5. Mridbhakshanajanya Pandu: - Bala-Varna-Agni Nash (loss of strength, complexion, and power of digestion metabolism), Ganda-Akshikuta-BhruPad-Nabhi-Mehan Shotha (oedema on cheek, eye socket, eyebrow, feet, umbilical region, genital parts), Krimi Koshta (Appearance of intestinal worm), Atisaryet Mala Sasruka Kapha (diarrhoea associated with blood and mucus).

SAMPRAPTI (PATHOGENESIS) [26]

Acharya Charaka has mentioned the Samprapti of Pandu in Chikitsa Sthan. According to him, due to consumption of Nidana Pitta located in the Hridaya (Sadhak Pitta) gets aggravated and being expelled from Hridya by powerful Vata and it enters the DashDhamanya (attached to the heart) and circulates all over the body. This aggravated Pitta reaches the space between skin and muscle tissue and brings vitiation in Kapha, Vata, Asrika, Twaka and Mamsa. This leading to abnormal types of colouration like Pandu, Haridra and Harita to the skin.

SAMPRAPTI GHATAKA: [27]

- Dosha-Pitta Pradhan Tridoshaja

- Pitta - Sadhaka, Ranjaka and Bhrajaka

- Kapha-Avalambaka, Kledaka

- Vyana-Vyan Vayu

- Dushya - Twaka, Rasa, Rakta, Mamsa and Meda.

- Strotas - Rasavaha, Raktavaha

- Stroto Dushti - Sanga and Vimarga Gamanam.

- Agni - Jatharagni and Dhatvagni.

- Agni Dushti - Mandagni

- Udbhavasthaan - Amashaya

- Adhishthana - Twaka Mamsa Abhyantara

- Vyaktasthaan - Twaka

- Sancharasthaan-Twaka \& Mamsa

- Svabhav-Chirkari

\section{SADHYA-ASADHYATVA:}

Patient of persistence chronic Pandu Roga whose Dhatu gets Khar does not cure. Also develops oedema observes all the objects yellowish in colour. Sharir Dhatus becomes Ruksha and a decrease in Bala and Varna occurs and Shotha develops. Rogi suffers from constipation and passes loose stools with mucus having greenish discolouration and becomes Deena, suffers from Murcha and Trushna. ${ }^{[28]}$ 


\section{CHIKITSA:}

\section{According to Acharya Charak: ${ }^{[29]}$}

Tatra Panduvamyi Snigdhateekshnaurdhvaaranulomikeh

Sansodhyo Mriduvitikteeh Kaamli Tu Viraichne. (Ch.Ch.16/40)

According to Acharya Charak in Sadhya Pandu Rog, Teekshna Vaman and Virechan should be done.

According to Acharya Sushruta: ${ }^{[30]}$

Harechha Doshan Bahushoalpamatrach Shvayedhhi Doshesvtinirharatesu (Su. Ut.44/22)

Means in Pandu Roga, Dosha which get situated in Dhatus, Srotas and Ashayas should be removed by Vaman and Virechan repeatedly if not done so then these Doshas cause Shotha in the different body part. Snehana Karma: in Pandu Rogi there is Sneha- Abhava (deficiency) and the Doshas get adhered to Shakhas therefore Snehan is essential to bring the Doshas in Koshtha and correct Rukshata. In Pandu Rogi both Bahya and Abhyantara Snehana are indicated. For Abhyantara Snehana Acharya Charak indicated some medicated Ghee i.e., Panchagavya Ghrit, Mahatiktak Ghrit, and Kalyanak Ghrit etc.

Vamana and Virechana Karma: Samyaka Snehan and Swedana bring the Doshas into Koshtha and by the action of Vaman or Virechana Karma they are expelled out of the body by their action. Virechana is considered as best Shodhanopakarma for Pitta Dosha. So, Virechana is most suitable in Pandu Roga.

Shamana Chikitsa:

- Vishesha chikitsa:

- In Vatika Pandu Snigdha Guna Pradhan Aushadha are to be used internally.

- In Pittaja Pandu Tikta Rasa and Shitaveerya Pradhan Aushadha are to be used internally.

- In Kaphaja Pandu Katu-Tikta Rasa Yukta and Ushna Veerya Pradhan Aushadha are to be used internally.

- In Sannipataja Pandu Mishrit Guna Aushadha are to be used internally.

- In Pandu Poga Vanaspatika and Khanija Yoga, Asava Arishta, Avaleha, Churna Yoga, Vati Yoga are used.
- Mridbhakshana Pandu: The ingested soil should be removed from the body by Tikshna Sansodhan (Vaman and Virechana) by evaluating the Shaaririk and Agni Bala of Rogi. After the Shodhana when the soil gets out of the body then $A g$ nivardhak and Balvardhak medicated Ghrit should be used to bring strength to the body.

\section{UPADRAVA:}

According to Acharya Sushruta Aruchi, Pipasa, Vaman, Jwara, Murdharuja, Agnisada Shopha, Kanthagata Abalatwa, Murcchha, Klama and Hrudayapidana are the Updrava of Pandu Roga. ${ }^{[31]}$

\section{PATHYA-APATHYA}

\section{$>$ Pathyahara:}

According to Acharya Charak: ${ }^{[32]}$

- Shalianna, Yava, Godhoom mixed with Yusha prepared from Mudga, Adhaki and Masur

- Jangal Mamsa Rasa

- Panchagavya Ghrit, Mahatiktaka Ghrit and Kalyanaka Ghrit used for Snehan Karma.

According to Acharya Susruta: ${ }^{[33]}$

- Pandu Rogi must use Arishta prepared from Guda, Sharkara (sugar) and Shahad (honey)

- Asava prepared from Mutra and Kshara should be used

- Jangala Mamsa Rasa added with Sneha (fat) and Amalaka Swaras should be used

Apathyahara:

In Bhaisajya Ratnavali following Apathya Aahar are mentioned: ${ }^{[34]}$

- Rakta Sruti, Dhoompan, Vaman Vega Dharan, Swedan and Maithoon are to be avoided by Pandu Rogi.

- Avoid consumption of Shimbi, Patrashaak, Ramath, Masha, Ambupaan, Pindyaak, Tambul, Sarshapa, and Sura.

- Intake of water of rivers like those originating from Vindhya and Sahyadri Mountain.

- All types of salt, sour edibles, Virudhha Anna (incompatible foods), food that is Guru (heavy to digest) and Vidahi (cause a burning sensation). 


\section{ARISHTA LAKSHANA}

Acharya Sushruta mentioned fatal signs and symptoms of Pandu Roga in Sutra Sthana (S.Su.33/23), which are ${ }^{[35]}$

- Pandu Dhantnakha

- Pandu Netra

- Pandu Shangtadarshi

\section{DISCUSSION}

Pandu Roga is Pitta pradhana vyadhi, Pitta is responsible for the normal colour of the body but when it gets vitiated, Panduta (Pallor) occurs. Though Pitta is Pradhana Dosha in Pandu Roga, Vata Dosha also plays a crucial role in the manifestation of Pandu Roga, mainly Vyana Vayu has a relation with Samprapti of Pandu Roga. Pandu is a Rasvaha Srotas Vyadhi from which a lot of people suffer. In Samhitas most of the Acharyas have described five types of Pandu Roga, i.e., Vatika, Paittika, Kaphaja, Tridoshaja and Mridabhakshhanajanya Pandu.The daily faulty routine activity related to mental or physical, faulty dietary habits like Mridikabhakshana, taking food deficient in quality and quantity, Nidanarthaka Roga is some etiological agents of Pandu Roga. Acharya Charaka mentioned three premonitory Symptoms of Pandu Roga i.e., Hridyaspandanam, Rokshyam and Shram which indicate its future presence. Also, in Charak Samhita Samanya and Visheshrupa of Pandu Rog is mentioned. Pandu is Sadhya Roga but in later stages, due to chronicity, it develops some complications. Hence, it is necessary to treat it in the early stage. According to Acharya Charak in Sadhya Pandu Rog medicated Teekshna Vaman and Virechan should be done. For the diagnosis and effective treatment, a physician must have complete knowledge of Pandu Roga by different Samhitas.

\section{CONCLUSION}

Now a day, numbers of patients suffering from Pan$d u$ Vyadhi are seen due to modern lifestyle, improper dietary habits in routine and the use of modern medicines. Pandu is a Varnopalakshita and Pitta Pradhana Vyadhi which is responsible for the normal colour of the body. Pandu can be correlated with
Anaemia. In Ayurvedic literature vast description of Pandu Roga and Chikitsa is given. To treat a Pandu Rogi, a physician must have complete knowledge of different aspects of Pandu like Nidan, Roopa, Poorvaroopa, Samprapti, and several Chikitsa Yoga, Sadhyaasadhyta, Arishtalakshan etc. from all Samithas, Nighantu, and other literature.

\section{REFERENCES}

1. Agnivesh, Kashinath Shastri, Gorakhnath Chaturvedi, Vol. II, Re-edition, Chap. 16/4, Varanasi; Chaukhambha Bharati Academy, 2004; 487

2. Ambika Datta Sastry, Sushrutha samhita, Uttara tantra, $7^{\text {th }}$ Edition, Chaukambha Sanskrit Samsthan, Varanasi, 1990, 286p.

3. Pandey Ajay Kumar, Textbook Of kaya chikitsa, Vol 2, Chapter 2, Chaukhambha Publications, New Delhi, First Edition 2019, P-167

4. Urvi R Dave, Anup Thakar. A clinical study of panduroga w.s.r to iron deficiency anaemia and its management with dhatriyarihta and Pandughna Vati.www.iamj.in - volume3; Issue7; ISSN: 2320 5091; July-2015, 1917pg.

5. Ralston H. Stuart et.al. Davidson's - Principle and Practice of Medicine, edited by Christopher Haslett, Elsevier Publication 2018, $23^{\text {rd }}$ edition, p-923

6. G. Ramadevi, S. Jonah, U.N. Prasad. A clinical study on the effect of Dhatri lauha in Garbhinipandu (IDA) Int. J. Res. Ayurveda Pharma 2014; 5(6); 708-712.)

7. Parthibhan P, Chilambuselvi P, Sasireka R, Samraj K. Evaluation of haematinic activity of the Siddha Drug Pitha Paandu Maathirai on Phenyl Hydrazine induced anaemic rats International Journal of Research in Pharmacy and Biosciences August 2015; 2(7): 23-27

8. Kawaljit K. Anaemia 'a silent killer' among women in India: Present scenario. European Journal of Zoological Research 2014; 3(1): 32-36. 5.

9. Malhotra P, Kumari S, Kumar R, Varma S. Prevalence of anaemia in adult rural population of North India. Journal of the Association of Physicians of India Jan 2004; 52: 18-20

10. Pandey Ajay Kumar, Textbook Of kaya chikitsa, Vol 2, Chapter 2, Chaukhmbha Publications, New Delhi, First Edition 2019, P-167

11. Taranath Tarkavachaspati. "Shabdasthome Mahanidhi”. Veedanyantra Press, Calcutta 1976

12. Pandey Ajay Kumar, Textbook Of kaya chikitsa, Vol 2, Chapter 2, Chaukhmbha Publications, New Delhi, First Edition 2019, P-168

13. Shastri Ambikadatta, susruta samhita, ayurveda tatvasandipika Hindi commentary, Vol. II, Chp. 44/15, Chaukhambha Sanskrit sansthan, Varanasi; reprint edition 2014; p-365 
14. Ambika Datta Sastry, Sushrutha samhita, Uttara tantra, 7 th Edition, Chaukambha Sanskrit Samsthan, Varanasi, 1990, 286p.)

15. Rani Khushboo, Gujjarwar Vidula, Gujjarwar Shriniwas; Acta Scientific Nutritional Health, "Mridabhakshanjanya Pandu-Review Article; 3;4;2019, P-6669

16. Shastri SN. "Panduroga Chikitsa adhyayah". In Carak Samhita 1st edition. Varanasi, IN: Chaukhamba Bharati Acadamy 2 (2013): 486.

17. Shastri, A. D. "Pandurogpratishedhoupkram Varnan". In Susruta Samhita Part II 1st edition. Varanasi, IN: Chaukhamba Sanskrit Sansthan (2013): 365.)

18. Tripathi Pt. Harihara Prasad Harita Samhita Hari Hindi VyakhyaSahita, Varanasi, Chuakhambha Krishna Das Academy, $2^{\text {nd }}$ Edition,2009, Tritiya Sthana, Chapter 21, Pg. 358)

19. Agnivesh, Charaka, Dradhabala, Pt. Kashinatha Shastri and G. Pandeya; Charaka Samhita, Vidhyotini Hindi commentary, Chikitsa Sthana,16/7-9, Chaukhamba Sanskrit Sansthan, 6th edition 2000, p.415

20. Shastri Ambikadatta, susruta samhita, ayurvedatatvasandipika Hindi commentary, Vol. II, Chp. 44/3, Chaukhambha Sanskrit sansthan, Varanasi; reprint edition 2014; p-364

21. Agnivesh, Charaka, Dradhabala, Pt. Kashinatha Shastri and G. Pandeya; Charaka Samhita, Vidhyotini Hindi commentary, Chikitsa Sthana,16/12, Chaukhamba Sanskrit Sansthan,6th edition 2000, p.416.

22. Sushruta, A. Shastri, Sushruta Samhita, Ayurvedtatva Sandipika Hindi commentary, Uttartantra 44/5, Chakhambha Bharti Academy, Varanasi, Reprint2013, p.366

23. Agnivesh, Charaka, Dradhabala, Pt. Kashinatha Shastri and G. Pandeya; Charaka Samhita, Vidhyotini Hindi commentary, Chikitsa Sthana,16/13-16, Chaukhamba Sanskrit Sansthan,6th edition 2000, p.416.

24. Agnivesh, Charaka, Dradhabala, Pt. Kashinatha Shastri and G. Pandeya; Charaka Samhita, Vidhyotini Hindi commentary, Chikitsa Sthana,16/3, Chaukhamba Sanskrit Sansthan, 6th edition 2000, p.414.

25. Agnivesh, Charaka, Dradhabala, Pt. Kashinatha Shastri and G. Pandeya; Charaka Samhita, Vidhyotini Hindi commentary, Chikitsa Sthana,16/19-22, Chaukhamba Sanskrit Sansthan, 6th edition 2000, p.417418.

26. Agnivesh, Charaka, Dradhabala, Pt. Kashinatha Shastri and G. Pandeya; Charaka Samhita, Vidhyotini Hindi commentary, Chikitsa Sthana,16/9-11, Chaukhamba Sanskrit Sansthan, 6th edition 2000, p.415.

27. Byadgi S. Parameswarappa, Textbook Of Vikrti Vijnana \& Roga Vijnana, Vol.2, Chapter 1/17, Chaukhmbha Publications, New Delhi, Reprint Edition 2019 P-64
28. Tripathi Brahmanand, Charaka Samhita, Hindi commentary, Vol. II, Chap. 16/31-32, Chaukhambha Surbharati prakashan, Varanasi; 2015; p-595

29. Tripathi Brahmanand, Charaka Samhita, Hindi commentary, Vol. II, Chap. 16/41-42, Chaukhambha Surbharati prakashan, Varanasi; 2015; p-598

30. Shastri Ambikadatta, Sushruta Samhita, ayurvedatatvasandipika Hindi commentary, Vol. II, Chp. 44/20, Chaukhambha Sanskrit sansthan, Varanasi; reprint edition 2014; p-373

31. Shastri ambikadatta, susruta samhita, ayurveda tatvasandipika Hindi commentary, Vol. II, Chp. 44/15, Chaukhambha Sanskrit sansthan, Varanasi; reprint edition 2014; p-371

32. Tripathi Brahmanand, Charaka Samhita, Hindi commentary, Vol. II, Chap. 16/41-42, Chaukhambha Surbharati prakashan, Varanasi; 2015; p-598

33. Shastri Ambikadatta, susruta samhita, Ayurvedatatvasandipika Hindi commentary, Vol. II, Chap. 44/41, Chaukhambha Sanskrit sansthan, Varanasi; reprint edition 2014; p-378

34. Shastri Ambikadatta; Bhaisajyaratnavali Vidyotni Hindi Commentary Chaukhamba Sanskrit Sansthan Varanasi Chapter,12 P-277

35. Sharma Anantram, susruta samhita, susrutavimarsini Hindi commentary, Vol. I, Chap. 33/23, Chaukhambha Surbharti prakashan, Varanasi; edition 2013; p-262

\section{Source of Support: Nil \\ Conflict of Interest: None Declared}

How to cite this URL: Shivam Kumar Nigam et al: A Critical Review Article On Pandu W.S.R. Anaemia. International Ayurvedic Medical Journal \{online\} 2021 \{cited September 2021\} Available from: http://www.iamj.in/posts/images/upload/2144_2150.pdf 